\title{
ANALISIS KLASTERISASI MALWARE: EVALUASI DATA TRAINING DALAM PROSES KLASIFIKASI MALWARE
}

\author{
Denar Regata Akbi ${ }^{1)}$, Arini R Rosyadi ${ }^{2}$ \\ 1, 2) Universitas Muhammadiyah Malang \\ e-mail: dnarregata@umm.ac.id ${ }^{1)}$, arini.rosyadi@gmail.com ${ }^{2)}$
}

\begin{abstract}
Training data is an important part of the classification process. Especially if the data is used to create a malware detection system. This study compared training data generated from two previous studies, the data used in both studies were android malware data based on the frequency of the system call of 600 data. The first study classifies and produces 4 types of malware, while the second research clusters and produces 8 clusters. From the two studies, researchers evaluated training data from each study to get more accurate results of training data, using 50 test data, researchers conducted evaluations and trials using the kNN algorithm. The results obtained, the use of training data based on the results of clustering in the classification process is more recommended, the results of the first error Prediction study: 0.995 while in the second study: 0.998. Recall results and accuracy using the cross-validation method, the first study, Recall: 0.665 accuracy: 0.66, second study, Recall: 0.893 accuracy: 0.89, while the Recall Results and accuracy using the percentage split method, the first study, Recall: 0.657 accuracy: 0.65, second study, Recall: 0.798 accuracy: 0.79 . Based on the results, the clustering process that uses frequency data from the malware system calls, produces training data that is more accurate than the training data produced by naming software for malware.
\end{abstract}

Keywords: training data, classification process, clustering process, malware, system call.

\begin{abstract}
ABSTRAK
Data latih merupakan salah satu bagian penting pada proses klasifikasi. Terutama jika data tersebut digunakan untuk membuat sistem pendeteksi malware. Penelitian ini melakukan perbandingan data latih yang dihasilkan dari dua penelitian yang telah dilakukan sebelumnya, data yang digunakan pada kedua penelitian tersebut merupakan data malware android berdasarkan frekuensi system call sejumlah 600 data. Penelitian pertama melakukan klasifikasi dan menghasilkan 4 jenis malware, sedangkan penelitian kedua melakukan klastering dan menghasilkan 8 klaster. Dari kedua penelitian tersebut, peneliti melakukan evaluasi data latih dari masing masing penelitian untuk mendapatkan hasil data latih yang lebih akurat, dengan menggunakan data uji sejumlah 50, peneliti melakukan evaluasi dan uji coba dengan menggunakan algoritme kNN. Hasil yang didapatkan, penggunaan data latih berdasarkan hasil klastering pada proses klasifikasi lebih direkomendasikan, hasil Error Prediction penelitian pertama: 0,995 sedangkan pada penelitian kedua: 0,998. Hasil Recall dan akurasi menggunakan metode cross validation, penelitian pertama, Recall: 0,665 akurasi: 0,66, penelitian kedua, Recall: 0,893 akurasi: 0,89, sedangkan Hasil Recall dan akurasi menggunakan metode precentage split, penelitian pertama, Recall: 0,657 akurasi: 0,65, penelitian kedua, Recall: 0,798 akurasi: 0,79. Berdasarkan hasil pengujian, proses klastering yang menggunakan data frekuensi system call malware menghasilkan data latih yang lebih akurat dibandingkan dengan data latih yang dihasilkan dengan menggunakan suatu situs penamaan malware.
\end{abstract}

Kata Kunci: data latih, klasifikasi, klasterisasi, malware, system call.

\section{PENDAHULUAN}

$\mathrm{D}$ ATA latih merupakan salah satu bagian penting pada proses klasifikasi. Menurut [1] data latih yang digunakan dalam teknik pembelajaran, seperti untuk melakukan proses prediksi, harus memiliki data latih yang baik sehingga menghasil hasil prediksi yang baik pula. Pada tulisan lain [2] menyebutkan bahwa salah satu aspek penting yang wajib untuk diperhatikan dalam suatu proses klasifikasi adalah data latih yang digunakan sebagai model pembelajaran. Data yang digunakan pada penelitian ini, baik data latih ataupun data uji merupakan data system call android, system call merupakan mekanisme dari suatu program yang terpasang pada sistem operasi untuk meminta layanan 
pada kernel sistem operasi, proses seberapa sering suatu program meminta layanan pada kernel sistem operasi dinamakan frekuensi system call, dari frekuensi permintaan layanan tersebut, didapatkan fitur fitur dari malware untuk digunakan pada penelitian ini [3] [4] [5] [6].

Oleh beberapa pengembang, malware dirancang untuk melakukan kerusakan pada suatu sistem yang diinfeksi, aktivitas yang dilakukan diantaranya menggangu kinerja komputer, sistem operasi, mencuri data atau informasi rahasia secara ilegal [7] [8] [9]. Sehingga dengan begitu dibutuhkan adanya sistem yang dapat mendeteksi atau pun mencegah serangan malware [10]. Dari banyak teknik yang digunakan dalam sistem pendeteksi malware (anti-malware) teknik utama yang digunakan adalah SignatureBased, Anomaly-Based dan Specification-Based. Pada setiap teknik tersebut dapat digunakan pendekatan statis, dinamis maupun hybrid [11]. Berdasarkan karakteristiknya, malware terbagi menjadi beberapa variasi diantaranya adalah virus, trojan-horse, worm, backdoor, adware, spyware, rootkit dan lain sebagainya, walaupun memiliki karakteristik yang berbeda, tetapi tidak menutup kemungkinan terdapat malware yang memiliki lebih dari satu variasi dalam waktu yang sama [12].

Terdapat beberapa penelitian tentang malware yang melibatkan teknik data mining. Penelitian pertama dilakukan oleh Sendi dkk [13]. Penelitian ini dilakukan dengan mengumpulkan malware, yang nantinya digunakan pada dua aktivitas (penelitian) yang berbeda, yang berjalan pada sistem operasi android pada ponsel pintar. Selanjutnya malware-malware yang telah didapatkan dilakukan proses pelabelan secara manual menggunakan situs www.virustotal.com untuk mengetahui jenis malware dan banyakknya jenis malware yang digunakan sebagai data set. Selanjutnya penelitian ini menggunakan metode $k$-fold Cross Validation untuk menguji tingkat akurasi data latih pada proses klasifikasi menggunakan Algoritme SVM (Support Vector Machine).

Penelitian selanjutnya dilakukan oleh Denar [14] yaitu melakukan pengklasteran terhadap data set yang sama dengan data set yang digunakan pada penelitian [13] dengan menggunakan Algoritme kMeans. Penelitian ini menghasilkan nilai Sum Square Error yang digunakan sebagai pengujian hasil klaster dan juga penentuan nilai $k$ yang tepat sehingga layak untuk digunakan sebagai data latih.

Kedua penelitian yang telah disebutkan adalah penelitian yang dilakukan dengan tujuan untuk mendapatkan data latih yang baik yang dapat digunakan pada sebuah sistem pendeteksi malware berdasarkan pada frekuensi system call dari malware. Selain itu berdasarkan pada [1] dengan digunakannya data latih yang baik maka sistem pendeteksi malware yang dikembangkan dapat mendeteksi malware dengan baik dan tepat. Maka berdasarkan penelitian-penelitian tersebut, penelitian ini melakukan pembandingan dan analisis terhadap data latih yang dihasilkan oleh keduanya. Dengan harapan didapatkan data latih yang baik untuk dapat digunakan dalam suatu sistem pendeteksi malware. Pembandingan dan pengujian dilakukan dengan menguji tingkat akurasi dari data latih.

\section{Metode PENELITIAN}

Penelitian ini melakukan beberapa kegiatan yang diberikan pada Gambar 1. Pada beberapa aktivitas dalam penelitian ini telah dilakukan pada penelitian sebelumnya, sehingga hasil uji coba telah didapatkan pada penelitian sebelumnya. Pada Gambar 1 aktivitas yang dilakukan pada penelitian sebelumnya adalah aktivitas yang berwarna jingga dan biru. Dimana Aktivitas-aktivitas berwarna jingga adalah penelitian yang dilakukan oleh [13] dan Aktivitas-aktivitas berwarna biru adalah penelitian sebelumnya yang dilakukan oleh [14]. Sedangkan aktivitas pada penelitian ini adalah aktivitas berwarna hijau.

Secara garis besar penelitian ini melakukan analisis dari kedua penelitian yang telah dilakukan sebelumnya untuk mendapatkan data set yang baik sehingga layak untuk digunakan sebagai data latih pada suatu sistem pendeteksi malware pada ponsel pintar. Aktivitas pertama yang dilakukan dalam penelitian ini melakukan analisis dan perbandingan adalah melakukan pelabelan manual pada malware data set berdasarkan pada jumlah klaster yang dihasilkan oleh klastering. Selanjutnya mengumpulkan beberapa malware lain yang pada aktivitas selanjutnya digunakan sebagai data uji. Aktivitas selanjutnya adalah melakukan proses klasifikasi dengan menggunakan data latih dari kedua penelitian sebelumnya, [13] dan [14], dan mendapatkan nilai Precision dan Recall untuk menentukan keakuratan dari kedua data latih yang digunakan.

Untuk memudahkan dalam membaca dan memahami penelitian yang dilakukan, pada penjabaran 
selanjutnya data latih berdasarkan hasil proses klastering [14] disebut dengan Data Latih A dan data latih berdasarkan penelitian yang dilakukan oleh [13] disebut dengan Data Latih B.

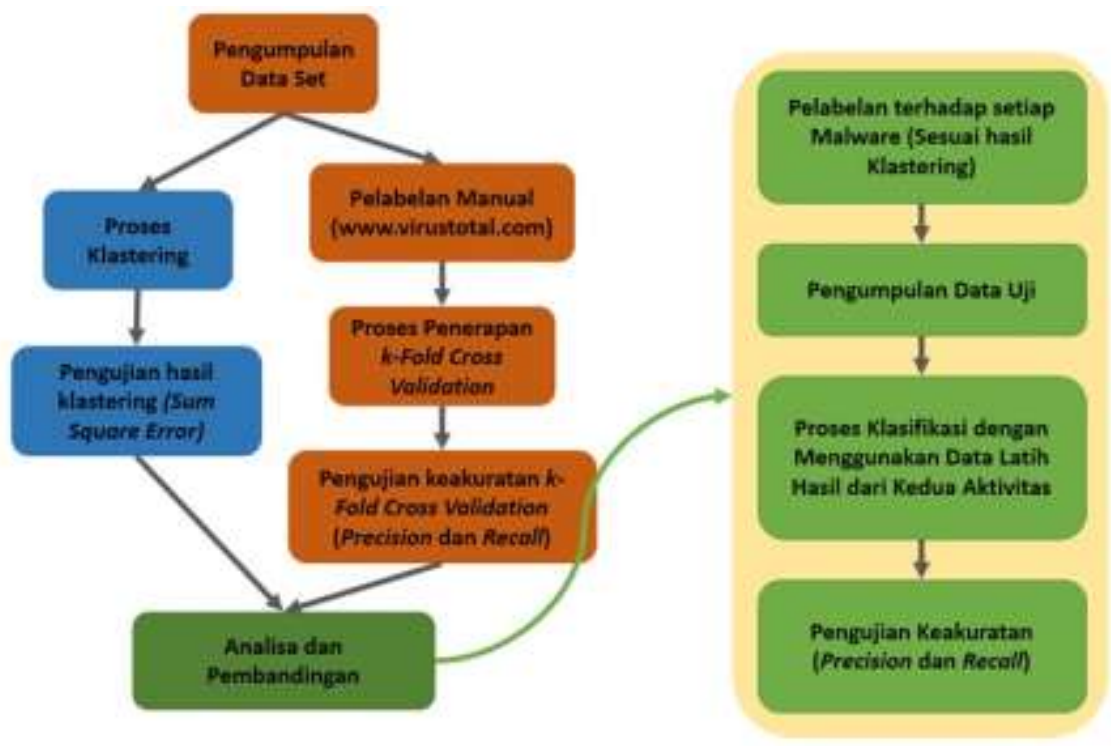

Gambar 7. Alur Kegiatan Penelitian

\section{A. Pelabelan Data Latih A}

Pada penelitian [14], data set yang digunakan hanya dilakukan proses klastering tanpa proses pelabelan terhadap setiap malware. Sehingga pada aktivitas ini, dilakukan pemberian label terhadap setiap malware yang berada pada data set sesuai dengan hasil klaster. Penamaan ini dilakukan dengan pemberian nama malwareCluster0, malwareClusterl, malwareCluster2 sampai dengan malwareCluster7 sesuai dengan nilai $k$ yang baik berdasarkan penelitian [14].

\section{B. Pengumpulan Data Set sebagai Data Uji}

Untuk menguji layak tidaknya suatu data latih menjadi suatu model dalam proses klasifikasi, tentunya dibutuhkan adanya data uji. Data uji digunakan selama proses klasifikasi dan dilakukan perhitungan nilai Precision dan Recall untuk dapat mengetahui tingkat akurasi dari proses klasifikasi yang dilakukan.

Aktivitas ini dilakukan berdasarkan pada penelitian [13]. Malware yang dikumpulkan pada aktivitas ini selanjutnya digunakan sebagai data uji pada proses klasifikasi. Sehingga sampai pada aktivias ini terdapat dua jenis data yang digunakan, yaitu data latih dari kedua penelitian sebelumnya (Data Latih A dan Data Latih B) dan data uji yang dikumpulkan pada aktivitas ini.

\section{Proses Klasifikasi dengan Menggunakan Dua Data Latih}

Pada aktivitas ini, dilakukan dua proses klasifikasi dengan menggunakan algoritme klasifikasi yang sama yaitu, Algoritme kNN, dan juga data uji yang sama. Yang membedakan dari kedua proses ini adalah data latih yang digunakan, yaitu Data Latih A dan Data Latih B.

\section{Pengujian Keakuratan Data Latih Kedua Proses Klasifikasi}

Aktivitas ini melakukan pengujian terhadap tingkat keakuratan dari kedua data latih yang digunakan pada proses klasifikasi. Hasil ini selanjutnya digunakan untuk proses analisis dan perbandingan. Pengujian keakuratan ini dilakukan dengan menghitung nilai dari Precision dan Recall.

\section{HASIL DAN PEMBAHASAN}

\section{A. Pelabelan Data Latih Berdasarkan Hasil Klastering}

Berdasarkan pada penelitian [14] didapatkan nilai $k$ yang baik berdasarkan perhitungan nilai Sum Square Error adalah $k$ sama dengan 8 dari beberapa percobaan variasi nilai $k$. Hal ini dapat dilihat pada Gambar 2 yang menunjukkan elbow pada grafik Sum Square Error berada pada $k$ sama dengan 8. 


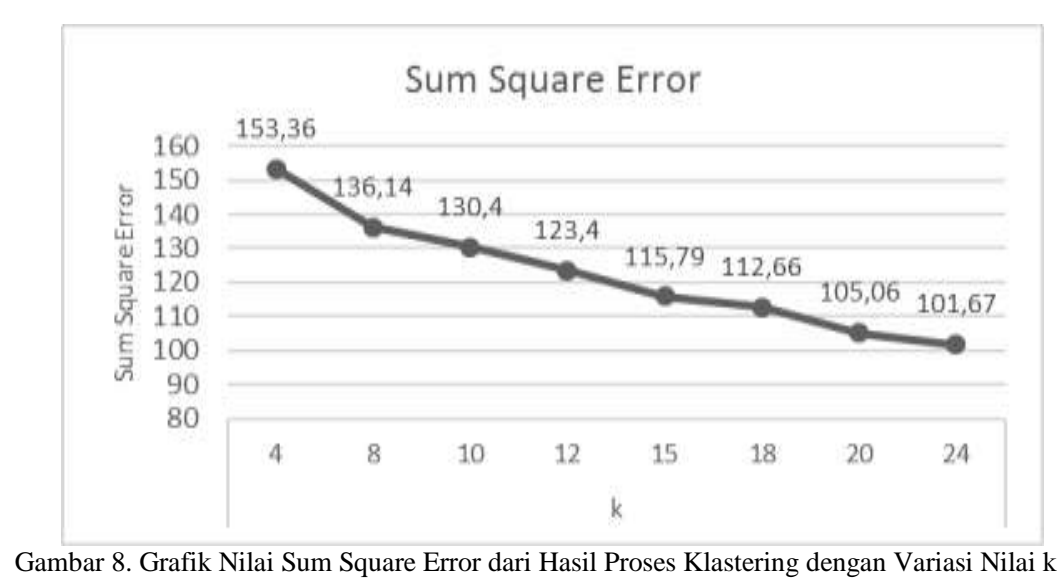

Berdasarkan pada Tabel I pada nilai $k$ sama dengan 8 maka didapatkan bahwa setiap klaster memiliki beberapa instans didalamnya. Terlihat bahwa klaster dengan jumlah terbanyak adalah klaster ketiga dengan jumlah instans adalah 410 malware dan klaster dengan jumlah instans terendah adalah klaster keempat dengan jumlah 2 malware. Dan delapan jenis malware sesuai dengan proses klastering yang dilakukan pada penelitian [14] adalah malwareCluster0, malwareCluster1, malwareCluster2, malwareCluster3, malwareCluster4, malwareCluster5, malwareCluster6 dan malwareCluster7.

TABEL I.

Hasil PElabelan Malware Dalam Dataset

\begin{tabular}{rrrrrrrr}
\hline Cluster0 & Cluster1 & Cluster2 & Cluster3 & Cluster4 & Cluster5 & Cluster6 & Cluster7 \\
\hline 25 & 46 & 1 & 2 & 298 & 3 & 128 & 42 \\
76 & 101 & 12 & 4 & 335 & 6 & 130 & 103 \\
82 & 112 & 41 & 5 & & 7 & 141 & 105 \\
96 & 154 & 48 & 8 & & 20 & 143 & 124 \\
98 & 170 & 90 & 9 & & 52 & 147 & \\
$\ldots$ & $\ldots$ & 122 & $\ldots$ & & $\ldots$ & $\ldots$ & \\
$\ldots$ & $\ldots$ & 251 & $\ldots$ & & $\ldots$ & $\ldots$ & \\
585 & 389 & & 599 & & 244 & 240 & \\
592 & 584 & & 600 & & 246 & 247 & \\
\hline $\mathbf{6 1}$ & $\mathbf{1 1}$ & $\mathbf{7}$ & $\mathbf{4 1 0}$ & $\mathbf{2}$ & $\mathbf{9 2}$ & $\mathbf{1 3}$ & $\mathbf{4}$ \\
\hline
\end{tabular}

\section{B. Pengumpulan Data Uji}

Data uji yang dikumpulkan pada aktivitas ini, adalah data malware yang sejenis dengan data set yang digunakan sebagai data latih. Yaitu berupa malware untuk sistem operasi android pada ponsel pintar yang nantinya didapatkan frekuensi system call yang dipanggil selama malware tersebut berjalan dalam sistem operasi. Situs yang digunakan untuk mendapatkan malware yang digunakan sebagai data uji adalah www.virusshare.com.

\section{Pengujian Keakuratan Data Latih Berdasarkan Kedua Penelitian}

Pada tahapan ini, dilakukan pengujian terhadap tingkat keakuratan dari data latih berdasarkan kedua penelitian yang telah dilakukan sebelumnya. Pengujian dilakukan dengan beberapa jenis percobaan, yaitu (1) Pengujian menggunakan data uji, (2) Pengujian menggunakan metode Cross Validation dan (3) Pengujian menggunakan metode Percentage Split. Ketiga pengujian tersebut menggunakan Aplikasi WEKA untuk mendapatkan nilai akurasinya.

- Pengujian Keakuratan Data Latih A

Data latih yang digunakan dalam pengujian ini adalah data latih yang dimana setiap malware telah masuk dalam salah satu dari delapan jenis malware yang ditentukan. Jumlah malware dalam tiap jenis malware diberikan pada Tabel 1. Pengujian tingkat akurasi pada data latih ini dilakukan pada tiga jenis pengujian, yaitu: 


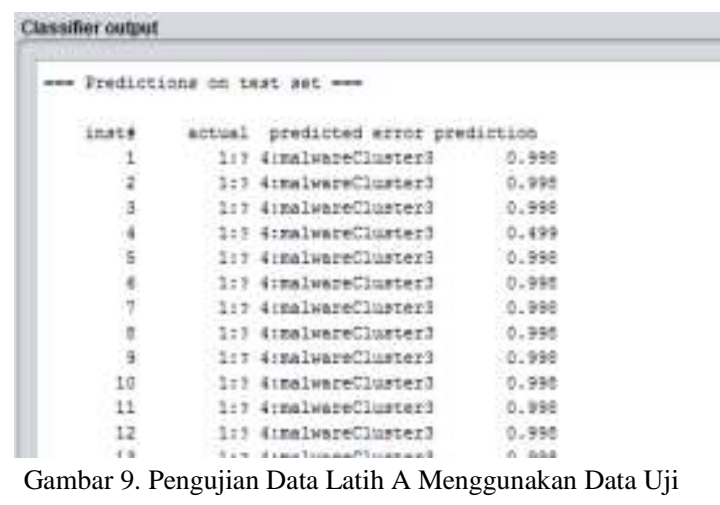

(1) Pengujian menggunakan data uji.

Data uji yang digunakan pada perbandingan ini adalah data uji yang berisi 50 malware yang didapatkan secara acak dan tidak diketahui jenis dari malware tersebut. Sehingga dengan menggunakan proses klasifikasi menggunakan WEKA dan Algoritme kNN, dapat diketahui jenis dari setiap malware.

Gambar 3 menunjukkan hasil Dari proses klasifikasi yang dilakukan dengan menggunakan data uji. Pengujian ini menghasilkan prediksi dari setiap malware yang terdapat dalam data uji bahwa seluruh malware masuk dalam jenis malwareCluster3 dengan nilai Error Prediction adalah 0.998 dan 0.499.

(2) Pengujian Menggunakan Metode Cross Validation.

Berdasarkan pada Gambar 4, pengujian dilakukan dengan proses klasifikasi yang pilihan pengujiannya menggunakan metode Cross Validation. Dari pengujian ini didapatkan nilai akurasi sebesar $89.33 \%$ dengan jumlah malware yang berada pada jenis malware yang benar adalah 536 dari total 600 malware yang digunakan. Sedangkan untuk tingkat akurasi data latih berdasarkan dari ratarata nilai Precision adalah tidak diketahui (?) dan rata-rata nilai Recall adalah 0.893.

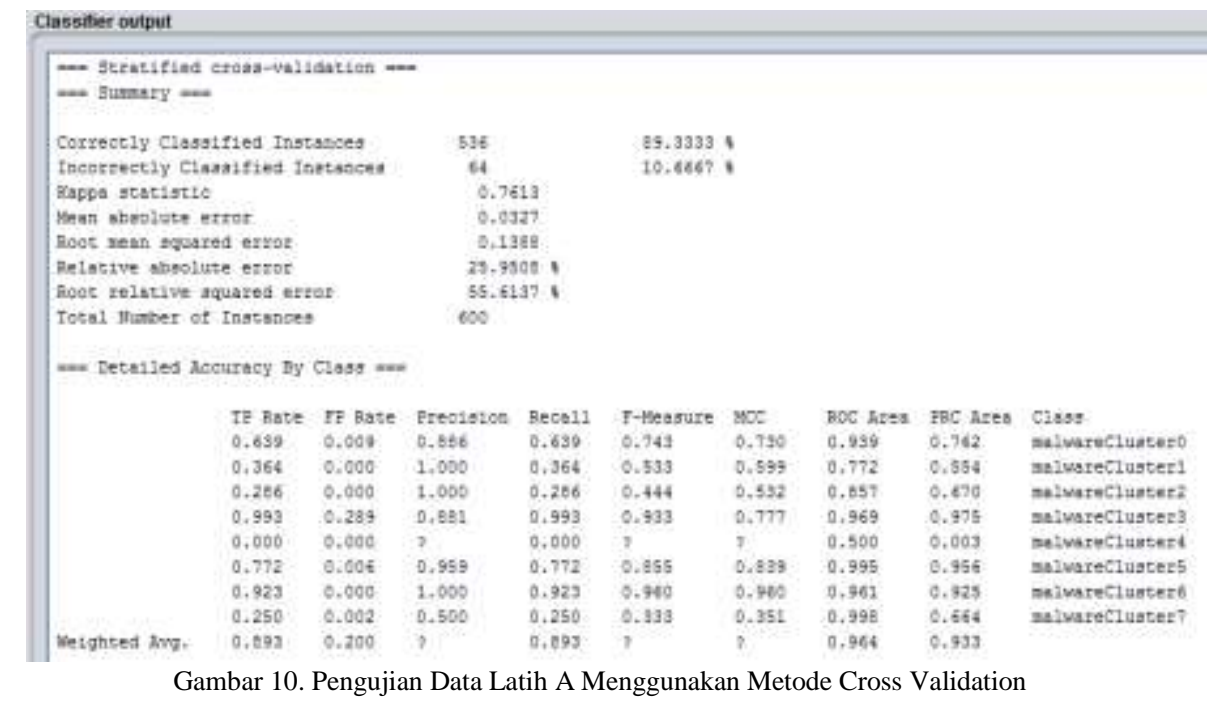

(3) Pengujian Menggunakan Metode Percentage Split.

Pada pengujian ini digunakan metode Percentage Split, dimana data latih yang dimiliki dibagi sesuai dengan porsi yang ditentukan untuk digunakan sebagai data latih dan data uji. Pada pengujian ini, pembagian dilakukan dengan porsi 70\% dari total data latih dan 30\% digunakan sebagai data uji.

Berdasarkan pada Gambar 5, pada pengujian proses klasifikasi, yang pilihan pengujiannya menggunakan metode Percentage Split, didapatkan nilai akurasi sebesar $79.77 \%$ dengan jumlah malware yang berada pada jenis yang benar adalah 335 dari total 420 malware (70\%) yang digunakan sebagai data latih dan 85 malware berada pada jenis yang tidak sesuai. Sedangkan untuk tingkat akurasi data latih berdasarkan dari rata-rata nilai Precision adalah tidak diketahui (?) dan rata-rata nilai Recall adalah 0.798 . 


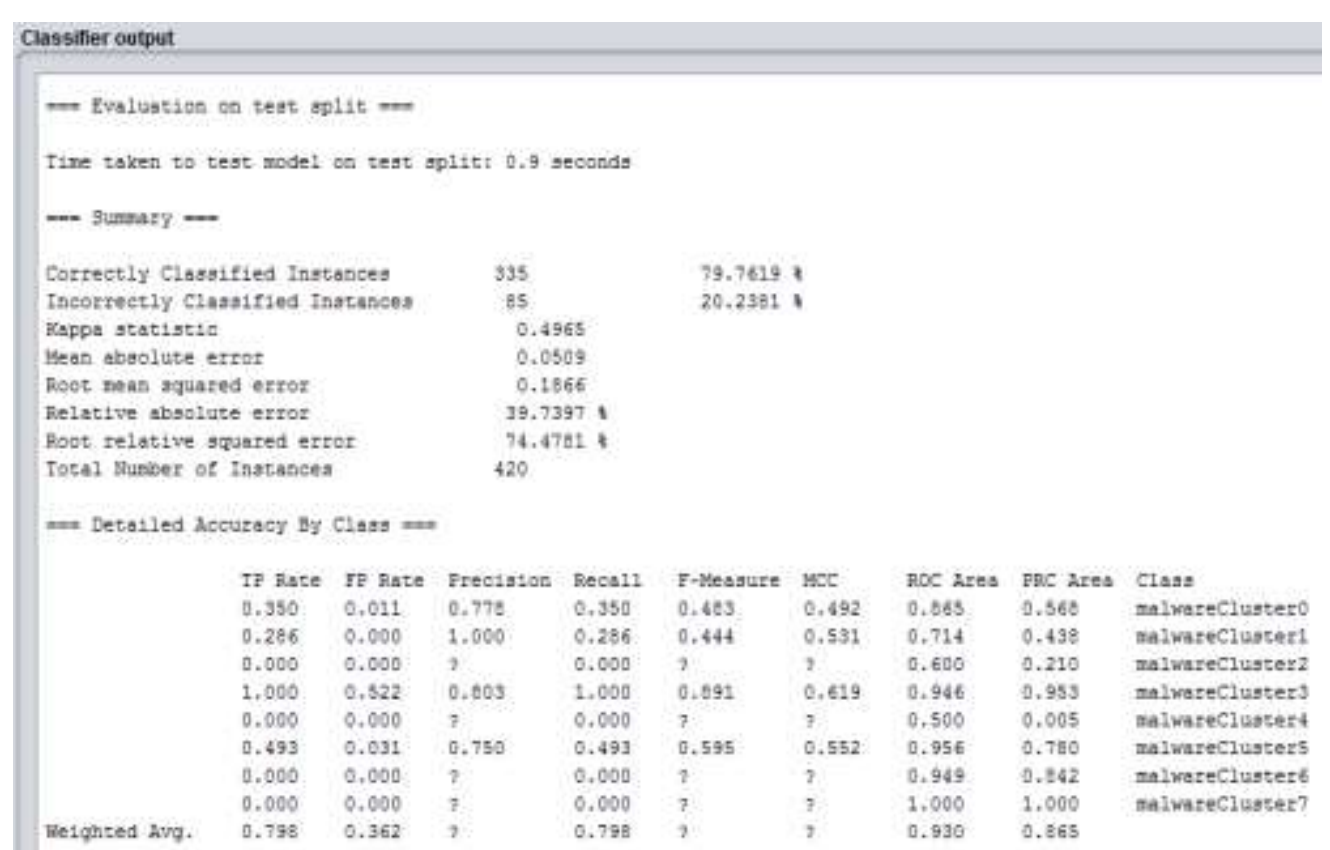

Gambar 11. Pengujian Data Latih A Menggunakan Metode Percentage Split

- Pengujian Keakuratan Data Latih B

Data latih ini didapatkan berdasarkan pada penelitian [13], dimana terdapat empat jenis malware yaitu Adware, Trojan, Plankton dan DroidKungfu. Seperti pada data latih berdasarkan hasil klastering, data latih ini juga dilakukan tiga pengujian yang berbeda untuk mendapatkan tingkat akurasinya. Pengujian ini menggunakan data uji dan skenario pengujian yang sama dengan yang digunakan pada pengujian menggunakan data uji pada Data Latih A.

(1) Pengujian menggunakan data uji.

Berdasarkan pada Gambar 6 didapatkan bahwa dari total 50 malware yang terdapat dalam data uji, malware-malware tersebut terbagi dalam beberapa jenis malware yang berbeda. Hasil klasifikasi menyebutkan bahwa 40 malware diprediksi sebagai Trojan, 6 malware sebagai Adware dan 4 malware sebagai Plankton. Dengan jumlah malware yang berbeda pada setiap jenis malware yang ada didapatkan nilai Error Prediction dari seluruh malware adalah 0.995.

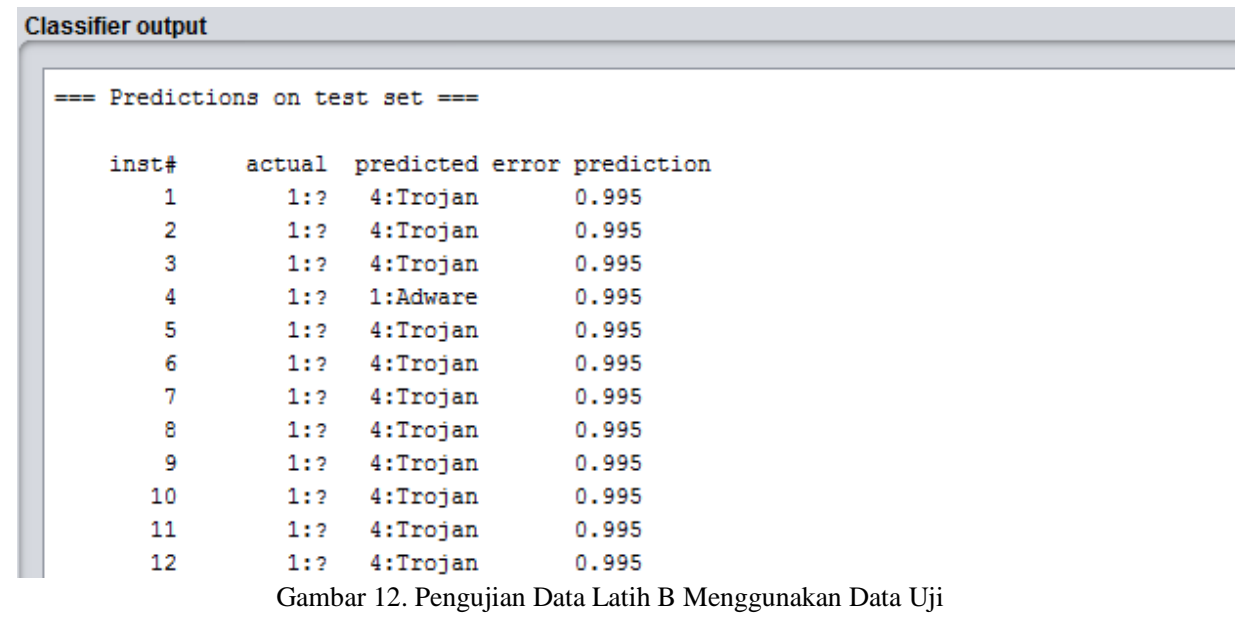

(2) Pengujian Menggunakan Metode Cross Validation.

Berdasarkan pada Gambar 7, pada pengujian terhadap data latih B, didapatkan nilai akurasi dari data latih yang digunakan sebesar $66.5 \%$ dengan jumlah malware yang berada pada jenis malware yang benar adalah 399 dari total 600 malware yang digunakan dan malware yang tidak berada pada jenis yang benar adalah 201 malware. Sedangkan untuk tingkat akurasi data latih berdasarkan dari rata-rata nilai Precision dan Recall adalah 0.667 dan 0.665. 


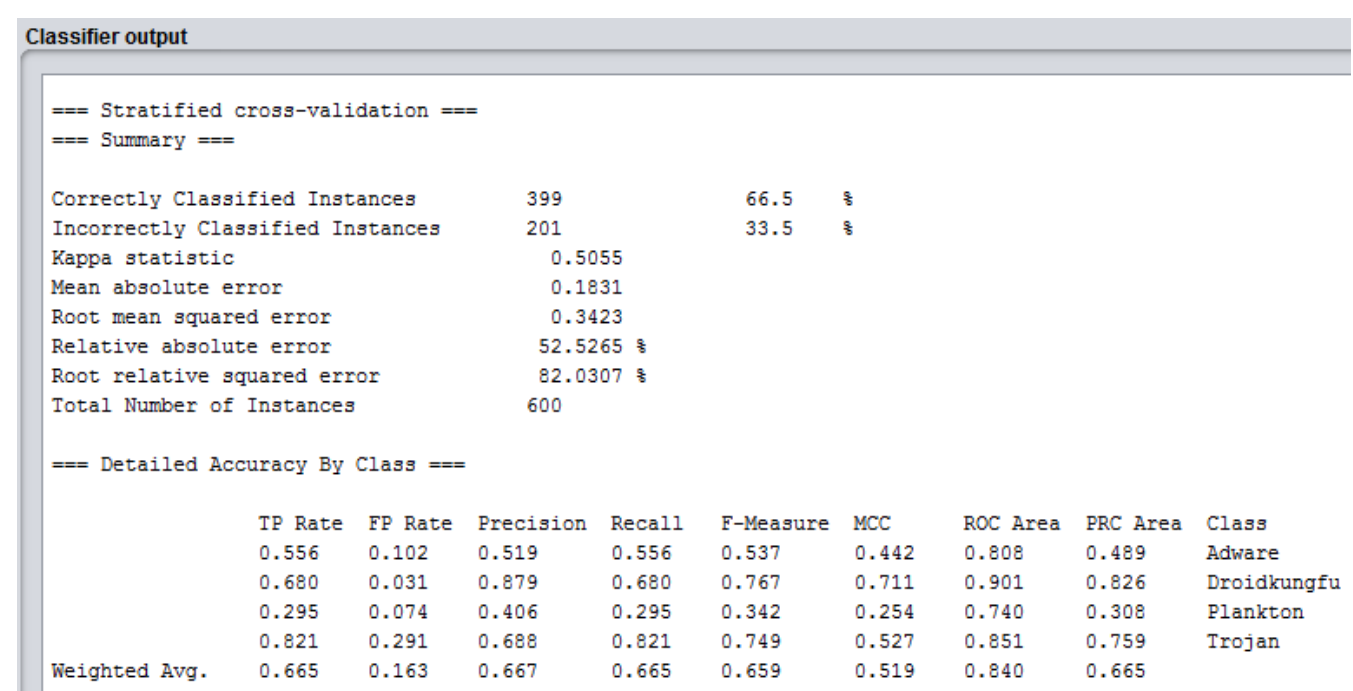

Gambar 13. Pengujian Data Latih B Menggunakan Metode Cross Validation

(3) Pengujian Menggunakan Metode Percentage Split.

Berdasarkan pada Gambar 8, pada pengujian ini didapatkan nilai akurasi dari data latih sebesar $65.72 \%$ dengan jumlah malware yang berada pada jenis malware yang benar adalah 276 dari total 420 malware (70\%) dan malware yang tidak berada pada jenis yang benar adalah 144 malware. Sedangkan untuk tingkat akurasi data latih berdasarkan dari nilai rata-rata Precision dan Recall adalah 0.650 dan 0.657 .

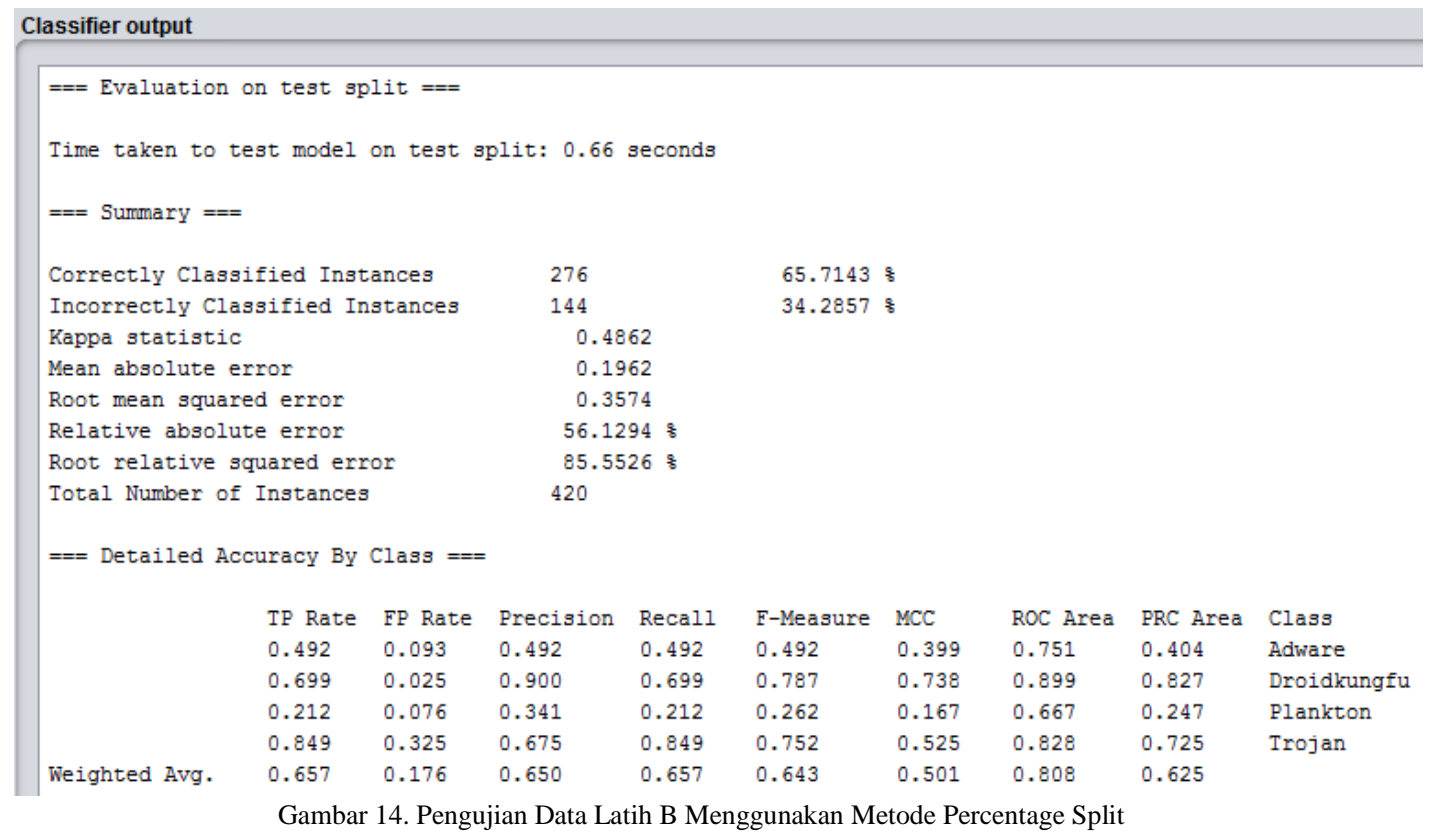

\section{Anlisa dan Pembandingan}

Berdasarkan pengujian yang telah dilakukan didapatkan hasil-hasil terhadap nilai Precision, Recall dan akurasi dari beberapa metode pengujian yang dilakukan. Sehingga untuk membandingkan hasilhasil dari pengujian diatas diberikan perbandingan dibawah ini:

- Pengujian menggunakan Data Uji

Pada pengujian data uji, $100 \%$ data uji dengan menggunakan Data Latih A berada pada satu jenis malware saja yaitu malwareCluster3 dengan variasi nilai Error Prediction adalah 0.495 dan 0.998 , sedangkan pada data uji dengan menggunakan Data Latih B masuk pada tiga jenis malware, yaitu Adware, Trojan dan Plankton. Pada ketiga jenis malware tersebut $80 \%$ (40) malware data uji berada pada jenis Trojan, $12 \%$ (6) malware berada pada jenis Adware dan $8 \%$ (4) malware berada pada jenis Plankton. Dan nilai Error Prediction pada pengujian Data Latih B adalah 0.995. 


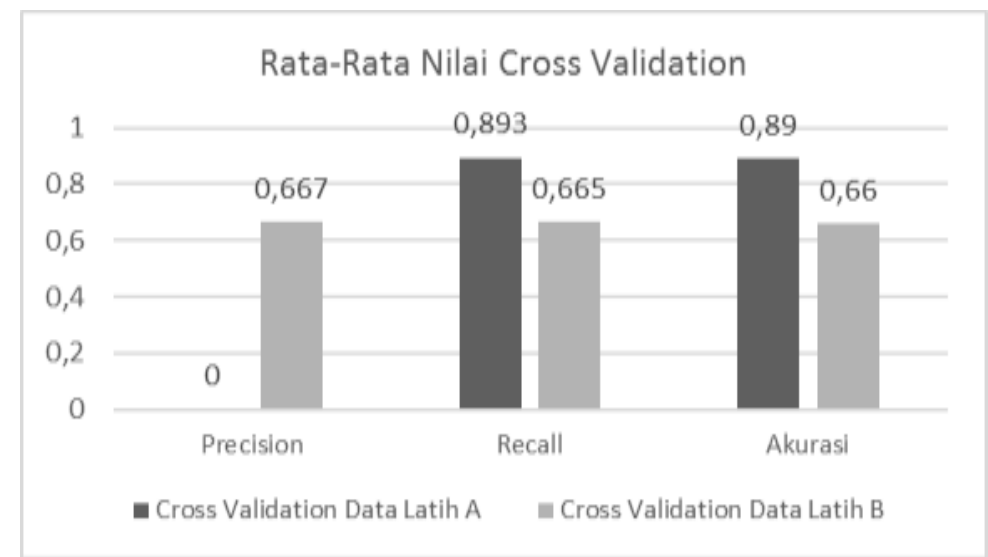

Gambar 15. Perbandingan Rata-Rata Nilai Precision, Recall dan Akurasi dari Metode Cross Validation antara Data Latih A dan Data Latih B

- Pengujian menggunakan Metode Cross Validation

Berdasarkan hasil pengujian kedua data latih menggunakan metode Cross Validation didapatkan perbandingan seperti pada Gambar 9. Pada grafik tersebut terlihat bahwa pada nilai Recall dan akurasi, Data Latih A memiliki nilai yang lebih tinggi dibandingkan pada Data Latih B. Khusunya pada nilai akurasi, Data Latih A lebih tinggi 0.23 atau 23\% dari pada nilai akurasi pada Data Latih B.

Sedangkan untuk rata-rata nilai Precision dianggap bernilai nol karena pada salah satu klaster, yaitu malwareCluster4, nilai False Positive dan True Positive bernilai 0. Dengan kata lain, tidak terdapat malware yang dikatakan berjenis malwareCluster4 yang diklasifikasikan secara benar atau salah oleh WEKA berada pada klaster malwareCluster4.

- Pengujian menggunakan Metode Percentage Split

Hasil pengujian kedua data latih menggunakan metode Percentage Split, dengan pembagian $70 \%$ untuk data latih dan 30\% untuk data uji, didapatkan perbandingan seperti pada Gambar 10. Pada grafik tersebut terlihat bahwa pada nilai Recall dan akurasi, Data Latih A memiliki nilai yang lebih tinggi dibandingkan pada Data Latih B. Pada nilai akurasi, Data Latih A lebih tinggi 0.14 atau 14\% dari pada nilai akurasi pada Data Latih B.

Seperti halnya pada pengujian menggunakan metode Cross Validation, untuk rata-rata nilai Precision pada pengujian ini dianggap bernilai nol karena pada beberapa klaster, yaitu malwareCluster2, malwareCluster4, malwareCluster6, malwareCluster 7 nilai False Positive dan True Positive bernilai 0. Dengan kata lain, pada malware-malware yang dikatakan berjenis malware-malware tersebut, tidak terdapat malware yang diklasifikasikan secara benar atau salah oleh WEKA berada pada klaster malwareCluster2, malwareCluster4, malwareCluster6, malwareCluster7.

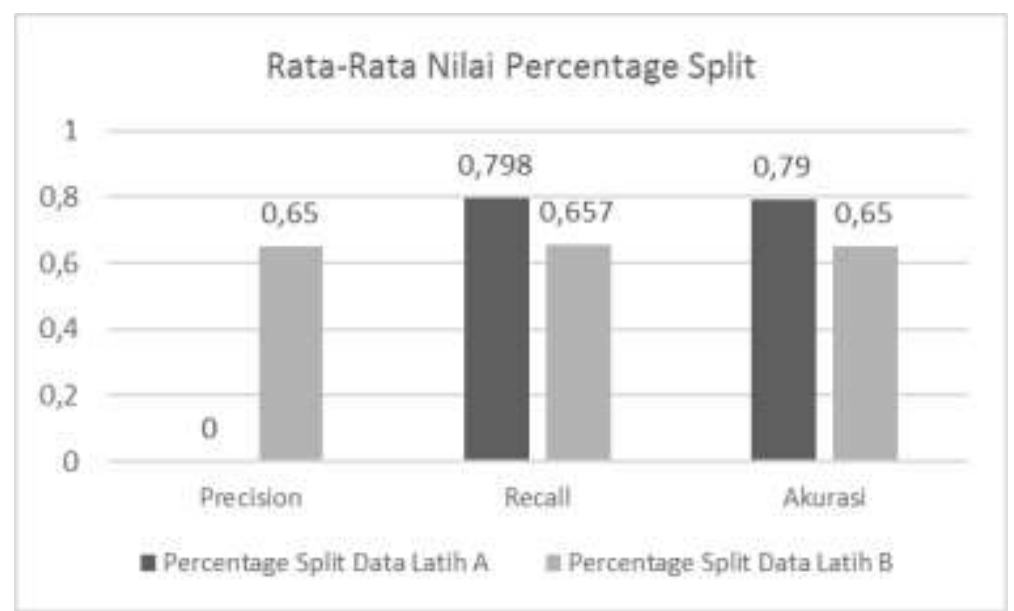

Gambar 16. Perbandingan Rata-Rata Nilai Precision, Recall dan Akurasi dari Metode Precentage Split antara Data Latih A dan Data Latih B 
Berdasarkan pada kedua pengujian (Pengujian menggunakan Metode Cross Validation dan Metode Percentage Split) Data Latih A memiliki nilai yang lebih baik. Hal ini dikarenakan pelabelan terhadap malware yang terdapat dalam data latih dilakukan dengan mengenali karakter system call dari setiap malware sesuai dengan penelitian [14] (dimana penelitian tersebut menggunakan system call sebagai fitur), dan pada proses pembadingan ini fitur yang digunakan adalah fitur-fitur yang sama pada penelitian Denar. Sedangkan pada penelitian Sendi, penamaan atau pelabelan malware dilakukan dengan menggunakan situs yang belum diketahui secara pasti parameter yang digunakan sebagai pengenalnya.

Menilik pada nilai rata-rata Precision pada pengujian pada Data Latih A, walaupun tidak didapatkan nilai yang tepat. Tetapi berdasarkan pada nilai Precision dari setiap kelas (klaster) yang dimiliki oleh setiap kelas (pada Gambar 4, Gambar 5, Gambar 7 dan Gambar 8 ), Data Latih A memiliki nilai Precision dan Recall yang lebih tinggi dibandingkan dengan Data Latih B. Sebagai contoh pada Data Latih A, pada pengujian menggunakan metode Cross Validation, setiap kelas memiliki nilai Precision diatas 0.5 bahkan terdapat beberapa kelas yang memiliki nilai Precision sama dengan 1.0. Sedangkan pada Data Latih B dengan metode pengujian yang sama memiliki nilai Precision diantara 0.4 sampai dengan 0.9 .

\section{KESIMPULAN}

Berdasarkan pengujian yang telah dilakukan pada penelitian ini, data latih yang dihasilkan melalui proses klastering menggunakan frekuensi system call malware lebih akurat dibandingkan dengan data latih yang dihasilkan dengan menggunakan suatu situs penamaan malware. Walaupun penamaan jenis malware yang dilakukan tidak dapat spesifik tetapi pengelompokan malware lebih tepat. Sehingga proses klasifikasi berdasarkan frekuensi system call malware yang menggunakan data latih yang dihasilkan melalui proses klastering pada lebih direkomendasikan dari pada data latih yang menggunakan situs yang ada seperti www.virustotal.com.

System call pada suatu proses yang sedang berjalan dalam sistem operasi komputer memiliki banyak informasi yang bisa didapatkan. Sehingga selain menggunakan frekuensi dari system call malware, pengembangan sistem pendeteksi malware juga dapat menggunakan informasi lain yang tersimpan dalam system call suatu malware.

\section{DAFTAR PUSTAKA}

[1] K. Madasamy and M. Ramaswami, "Data Imbalance and Classifiers: Impact and Solutions," International Journal of Computational Intelligence Research, vol. 13, pp. 2267-2281, 2017.

[2] K. Millard and M. Richardson, "On the Importance of Training Data Sample Selection in Random Forest Image Classification: A Case Study in Peatland Ecosystem Mapping," Remote Sens, vol. 7, no. 7, pp. 8489-8515, 2015.

[3] M. Dimjašević, S. Atzeni, Z. Rakamarić and I. Ugrina, "Evaluation Of Android Malware Detection Based on System Calls," in International Workshop on Security And Privacy Analytics. ACM, Salt Lake, 2016.

[4] R. Canzanese, S. Mancoridis and M. Kam, "System Call-Based Detection of Malicious Processes," in IEEE, Vancouver, 2015.

[5] R. Canzanese, S. Mancoridis and M. Kam, "Run-Time Classification of Malicious Processes Using System Call Analysis," in International Conference on Malicious and Unwanted Software (MALWARE), Fajardo, 2015.

[6] S. Malik, "Android System Call Analysis for Malicious Application Detection," International Journal of Computer Sciences and Engineering, vol. 5, no. 11, pp. 105-108, 2017.

[7] T. K. Barsiya, M. Gyanchandani and R. Wadhwani, "ANDROID MALWARE ANALYSIS : A SURVEY PAPER," International Journal of Control, Automation, Communication and Systems (IJCACS), pp. 35-42, 2016.

[8] M. Christodorescu, S. Jha, S. A. Seshia, D. Song and R. E. Bryant, "Semantics-aware malware detection," in IEEE Symposium on Security and Privacy, Oakland, 2005.

[9] S. Pai, A Comparison of Clustering Techniques for Malware Analysis, San Jose: San Jose State University, 2015.

[10] U. Bayer, P. M. Comparetti, C. Hlauschek, C. Kruegel and E. Kirda, "Scalable, Behavior-Based Malware Clustering," NDSS, pp. 8-25, 2009.

[11] N. Idika and A. P. Mathur, A Survey of Malware Detection Techniques, West Lafayette: Purdue University, 2007.

[12] E. Gandotra, D. Bansal and S. Sofa, "Malware Analysis and Classification: A Survey," Journal of Information Security, pp. 56-64, 2014.

[13] S. Herlambang, S. Basuki, D. R. Akbi and Z. Sari, "Deteksi Malware Android Berdasarkan System Call Menggunakan Algoritma Support Vector Machine," in SENTRA, Malang, 2018.

[14] D. R. Akbi and A. R. Rosyadi, "Klastering Android Malware Berdasarkan Frekuensi System Call Menggunakan K-Means," in SENTRA, Malang, 2018. 